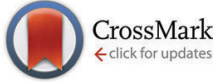

Cite this: New J. Chem., 2017, 41,2392

Received 21st September 2016, Accepted 30th January 2017

DOI: 10.1039/c6nj02985j

rsc.li/njc

\section{Synthesis and optimization of a reactive oxygen species responsive cellular delivery system $\dagger$}

\begin{abstract}
Ana M. Perez-Lopez $\ddagger$ Elsa Valero $\ddagger$ and Mark Bradley*
Reactive oxygen species play numerous roles in a number of pathological processes. Monitoring $\mathrm{H}_{2} \mathrm{O}_{2}$ is a powerful tool for imaging and therapy of diseases wherein oxidative stress is involved. In particular, we report a specific application of functional microspheres as sensors of $\mathrm{H}_{2} \mathrm{O}_{2}$. Reactive oxygen species responsive delivery systems were developed to detect in vitro peroxides thanks to the presence of a boronic ester which is readily cleaved with $\mathrm{H}_{2} \mathrm{O}_{2}$. This ROS-sensitive cleavable linker underwent a 1,6-elimination to disrupt fluorescence resonance energy transfer by coupled near-infrared fluorophores such as Cy5.5/Cy7. This technology would allow real-time monitoring of therapeutic regimes (and their success), as well as optical detection of inflammation.
\end{abstract}

\section{Introduction}

In healthy cells and tissues, there exists a delicate balance between the generation of reactive oxygen species and radical generation and a cell's antioxidant defences ${ }^{1,2}$ with both important for normal metabolism, and regulation of the cellular function. ${ }^{3,4}$ Reactive oxygen species (ROS) cover a number of oxygen-based metabolites including superoxide anion radicals $\left(\mathrm{O}_{2}{ }^{\bullet-}\right)$, hydrogen peroxide $\left(\mathrm{H}_{2} \mathrm{O}_{2}\right)$ and hydroxyl radicals $\left({ }^{\bullet} \mathrm{OH}\right)$. These species have been demonstrated to cause damage to various cellular components, effecting cellular proliferation and survival, ${ }^{5}$ as well as being found in many hypoxic tissues. Perhaps counter intuitively compounds such as hydrogen peroxide are potentially more damaging to DNA than hydroxyl radicals, since their lower reactivity provides a sufficient time for hydrogen peroxide to travel into the nucleus of a cell from its site of generation. ${ }^{6}$

$\mathrm{H}_{2} \mathrm{O}_{2}$ imbalance has potential as a trigger for tissue directed delivery, ${ }^{7-10}$ and has been extensively targeted with the synthesis of switch-on optical imaging probes. ${ }^{11-14}$ Tsien developed a strategy whereby $\mathrm{H}_{2} \mathrm{O}_{2}$ produced in the proximity of a cancer reacted with a so-called Activatable Cell Penetrating Peptide (ACPP) construct, inducing delivery of a labelled polyarginine scaffold into cells and with application in an in vivo inflammation model. ${ }^{15}$

The uptake of nano and microspheres $(0.2-5 \mu \mathrm{m})$ has been successfully established in a broad range of cell types, including adherent and suspension cultures of primary cells. The broad applicability of this approach has been demonstrated with the

School of Chemistry, University of Edinburgh, Joseph Black Building, David Brewster Road, Edinburgh EH9 3JJ, UK. E-mail: mark.bradley@ed.ac.uk $\dagger$ Electronic supplementary information (ESI) available. See DOI: 10.1039/c6nj02985j $\$$ These authors contributed equally to this work. "loading" of stem cells, giving rise to viable chimeras thus demonstrating their remarkable cellular biocompatibility. ${ }^{16-18}$

Here, ROS-cleavable linkers were designed, synthesised, loaded with a cargo and attached to microspheres, such that when these "carriers" entered cells undergoing oxidative stress cargo release was triggered. To allow evaluation of the cleavage of the ROSsensitive linker, FRET-based probes were synthesised, as shown in Fig. $1,{ }^{19}$ where cleavage of the ROS-cleavable linker by $\mathrm{H}_{2} \mathrm{O}_{2}$ perturbs the FRET system (consisting of the well-known FRET pair 5(6)-carboxyfluorescein ( $\lambda_{\text {ex/em }} 488 / 528 \mathrm{~nm}$ )/methyl red $\left(\lambda_{\text {Abs }} 480 \mathrm{~nm}\right)$ or the NIR cyanine dyes Cy5.5 $\left(\lambda_{\text {ex/em }} 675 / 694 \mathrm{~nm}\right) /$ Cy7 $\left.\left(\lambda_{\text {ex/em }} 743 / 767 \mathrm{~nm}\right)\right)^{20-22}$ As a second example a cell carrier consisting of a polycationic lysine-like peptide, ${ }^{23}$ which is resistant to proteolysis, non-toxic in vivo and has demonstrated a highly efficient cell entry profile ${ }^{24-34}$ was used to confirm the versatility of a ROS-sensitive linker.

This safety catch linker cleaves via the well-known oxidative rearrangement, which generates a phenol/phenolate which undergoes a 1,6-elimination reaction (as we described in 1997) ${ }^{35}$ to liberate a fluorescent label or cargo. ${ }^{36}$

\section{Experimental}

\subsection{Chemicals and apparatus}

All solvents and reagents were obtained from commercial suppliers and used without purification, unless otherwise stated. Microwave reactions were carried out using a Biotage Initiator instrument in sealed heavy-walled Pyrex tubes (Biotage AB, size $5 \mathrm{~mL}$ or $20 \mathrm{~mL}$ ). Microsphere couplings were carried out on an Eppendorf ThermoMixer ${ }^{\circledR}$ comfort and washed with centrifugation in a Heraeus Pico 17 centrifuge.

Thin Layer Chromatography (TLC) was carried out using Merck silica gel 60 F254 $(0.25 \mathrm{~mm})$ foil-backed plates with 


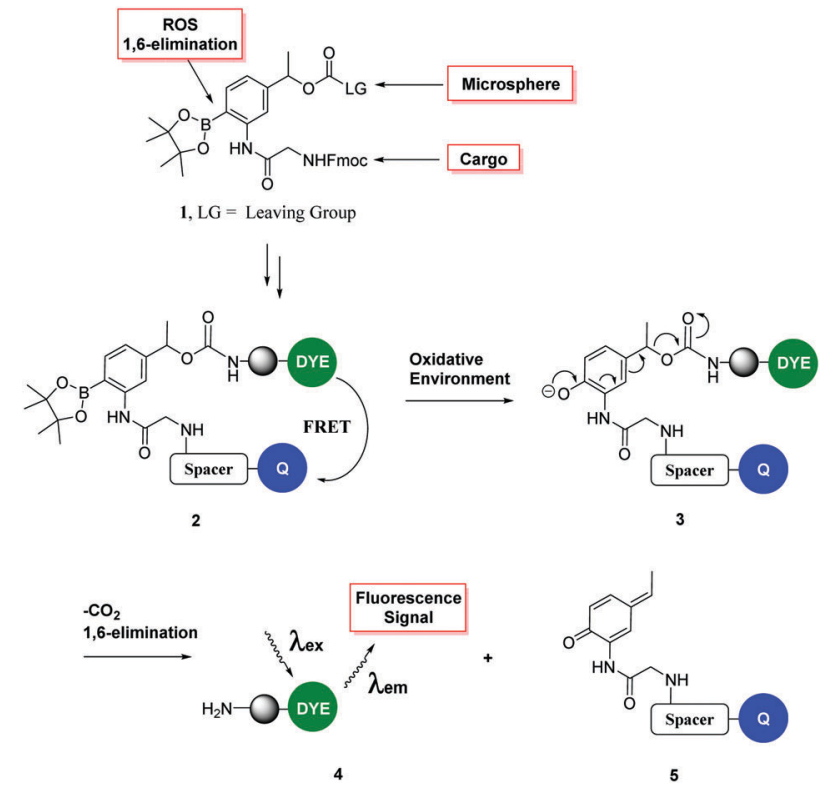

Fig. 1 Fluorescence "turn on" ROS-responsive cleavable linker. Upper: Compound 1 shows the three major elements of the linker - namely (i) its ability to attach to a variety of cargos via Fmoc chemistry; (ii) a leaving group to allow conjugation to a cellular carrier and (iii) cyclic boronate to allow peroxide mediated rearrangement to the phenol with subsequent 1,6-elimination. ${ }^{19}$ The lower figure shows the mechanism of cleavage and the designed FRET system.

visualisation by ultraviolet light. Flash chromatography was carried out using Silica $60 \AA$, particle size 35-70 micron under positive pressure.

High pressure liquid chromatography (HPLC) analyses were performed using the following eluents: (A) $\mathrm{H}_{2} \mathrm{O}+0.1 \%$ formic acid and (B) $\mathrm{MeOH}+0.1 \%$ formic acid. Analytical HPLC was performed on an Agilent 1100 analytical system with a Supelco Discovery ${ }^{\circledR} \mathrm{C} 18,5 \mu \mathrm{m}, 5 \mathrm{~cm}$ column coupled to a Polymer laboratories 100 ES evaporative light scattering detector (ELSD).

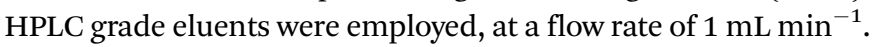
The following method was used: eluents A and B, 5 to $95 \%$ B over $8 \mathrm{~min}$, then $95 \% \mathrm{~B}$ for $1 \mathrm{~min}$. Semi-preparative reverse phaseHPLC purifications were performed on an Agilent Technologies HP1100 Chemstation eluting on an Eclipse XDB-C18 column $(9.4 \times 250 \mathrm{~mm}, 5 \mu \mathrm{m})$, at a flow rate of $2 \mathrm{~mL} \mathrm{~min}^{-1}$. Detection was carried out at $254 \mathrm{~nm}$. The following gradient was used: 5 to $50 \%$ A over $6 \mathrm{~min}, 50$ to $100 \%$ B for $30 \mathrm{~min}$.

High resolution mass spectrometry was measured in a Bruker MicroToF 2. Matrix assisted laser desorption ionisation-time of flight (MALDI-TOF) mass spectra were recorded using a Bruker Ultraflex Extreme MALDI TOFTOF instrument and analysed with the Bruker Daltonics flexAnalysis software. For peptide analysis, sinapic acid was used as a matrix and the positive ion mass spectra were recorded. The low resolution electrospray mass spectra (ES/MS) were recorded on an Agilent Technologies LC/MSD 1100 Quadrupole Mass Spectrometer (QMS) with an electrospray ion source.

Nuclear magnetic resonance experiments were run in a Bruker Avance NMR Spectrometer $400 \mathrm{MHz}$ or $500 \mathrm{MHz}$ for small molecular weight compounds. Chemical shifts are reported as $\delta$ in units of parts per million (ppm) relative to the indicated solvent. Multiplicities in ${ }^{1} \mathrm{H}$ NMR are reported as follows: $\mathrm{s}$ (singlet), d (doublet), t (triplet), q (quadruplet), dd (doublet of doublets), ddd (doublet of doublet of doublets), $m$ (multiplet). Coupling constants are reported as a $J$ value in Hertz $(\mathrm{Hz})$. The number of protons $(n)$ for a given resonance is indicated as $\mathrm{nH}$, and is based on spectral integration values.

Dynamic Light Scattering (DLS) and zeta potential were measured on a Zetasizer Nano ZS ZEN 3500 in molecular biology grade water in a disposable sizing cuvette for size measurements or clear disposable zeta cuvettes for zeta potential measurements.

Fluorescence spectrophotometry was performed on a Synergy ${ }^{\mathrm{TM}}$ HT Multi-Mode Microplate Reader from BioTek. Reader control is via BioTek's Gen ${ }^{\mathrm{TM}}$ Data Analysis Software.

Flow cytometry was performed on a BD FACS Aria ${ }^{\circledR}$ System using the BD FACS Diva ${ }^{\circledR}$ software. The data were analysed using the software Flowjo ${ }^{\circledR} 7.5$.

\subsection{Synthesis of ROS-cleavable linkers $1 \mathrm{a} / \mathbf{1 b}$}

Synthesis of compound 7. To a cold solution $\left(-15{ }^{\circ} \mathrm{C}\right)$ of Fmoc-protected glycine (7 g, $23.36 \mathrm{mmol}$ ) and 3-amino-4bromoacetophenone $6(5 \mathrm{~g}, 23.54 \mathrm{mmol})$ in pyridine $(70 \mathrm{~mL})$, phosphoryl chloride $\left(\mathrm{POCl}_{3}\right)(2.5 \mathrm{~mL}, 26 \mathrm{mmol})$ was added drop-wise. The mixture was stirred for 2 hours at $-15{ }^{\circ} \mathrm{C}$ and then allowed to warm to room temperature and was stirred for an additional hour. The reaction mixture was quenched with water $(8 \mathrm{~mL})$. The solvents were evaporated under reduced pressure. The crude reaction mixture was purified by precipitation in DCM. Yield: $100 \%$. HRMS: calcd for $\mathrm{C}_{25} \mathrm{H}_{21} \mathrm{~N}_{2} \mathrm{O}_{4} \mathrm{Br}_{1} 492.067920$, found 492.067903. ${ }^{1} \mathrm{H}$ NMR $\left(400 \mathrm{MHz}, \mathrm{CDCl}_{3}\right) \delta 8.93(\mathrm{~s}, 1 \mathrm{H}), 8.42(\mathrm{~s}, 1 \mathrm{H})$ $7.79(\mathrm{~d}, J=6.8,3 \mathrm{H}), 7.62(\mathrm{~d}, J=4.9,3 \mathrm{H}), 7.42(\mathrm{~m}, 2 \mathrm{H}), 7.33$ $(\mathrm{m}, 2 \mathrm{H}), 4.55(\mathrm{~d}, J=6.6,2 \mathrm{H}), 4.27(\mathrm{t}, J=6.4,1 \mathrm{H}), 4.09(\mathrm{~s}, 2 \mathrm{H})$, $2.62(\mathrm{~s}, 3 \mathrm{H}) .{ }^{13} \mathrm{C} \mathrm{NMR}\left(100 \mathrm{MHz}, \mathrm{CDCl}_{3}\right) \delta 197.10,167.53$, 143.56, 141.37, 137.18, 132.66, 127.86, 127.14, 124.89, 124.72, $121.75,120.11,67.52,47.08,45.81,26.69$.

Synthesis of compound 8. Compound 7 ( $4.5 \mathrm{~g}, 9.14 \mathrm{mmol})$ was dissolved in $82 \mathrm{~mL}$ of $95 \%$ ethanol. Sodium borohydride (1.42 $\mathrm{g}, 37.54 \mathrm{mmol}$ ) was added and the mixture was stirred. The reaction was completed after $1 \mathrm{~h}$ at room temperature. $500 \mu \mathrm{L}$ of ice-cold distilled water was slowly added using a pipette to the reaction mixture. The mixture was transferred to a centrifuge tube and was extracted with dichloromethane $(3 \times 10 \mathrm{~mL})$ by mixing the mixture with a pipette. The solvent was removed on a rotary evaporator. No purification was necessary. Yield: 100\%. HRMS: calcd for $\mathrm{C}_{25} \mathrm{H}_{23} \mathrm{~N}_{2} \mathrm{O}_{4} \mathrm{Br}_{1}$ 494.083570, found 494.082957. ${ }^{1} \mathrm{H}$ NMR (500 MHz, MeOD) $\delta 7.81(\mathrm{~d}, J=7.5,2 \mathrm{H}), 7.68(\mathrm{t}, J=9.5,2 \mathrm{H}), 7.58$ $(\mathrm{d}, J=6.3,1 \mathrm{H}), 7.35(\mathrm{ddd}, J=25.0,16.2,8.8,5 \mathrm{H}), 7.15(\mathrm{t}, J=8.2,1 \mathrm{H})$, $4.81(\mathrm{dd}, J=12.8,6.4,1 \mathrm{H}), 4.40(\mathrm{~d}, J=6.9,2 \mathrm{H}), 4.25(\mathrm{t}, J=6.9,1 \mathrm{H})$, $3.95(\mathrm{~s}, 2 \mathrm{H}), 1.44$ (d, $J=6.5,3 \mathrm{H}) .{ }^{13} \mathrm{C} \mathrm{NMR}(126 \mathrm{MHz}, \mathrm{MeOD})$ $\delta$ 169.94, 168.96, 157.82, 150.99, 147.18, 143.89, 141.20, 128.90, $127.40,126.78,124.85,121.44,120.02,119.56,118.70,117.40$, 80.29, 69.31, 66.80, 43.94, 24.98 .

Synthesis of compound 9. A dry reaction vessel was charged with $\mathrm{Pd}_{2}(\mathrm{dba})_{3}(13 \mathrm{mg}, 0.01 \mathrm{mmol})$ and tricyclohexylphosphine $\left(\mathrm{PCy}_{3}, 20 \mathrm{mg}, 0.07 \mathrm{mmol}\right)$ and flushed with nitrogen. $1 \mathrm{~mL}$ of 
dioxane was added and the resulting mixture was then stirred for 15 minutes at room temperature. A $100 \mathrm{~mL}$ flask containing $500 \mathrm{mg}$ of 8 was charged with bis(pinacolato)diboron $(258.7 \mathrm{mg}$, $1.02 \mathrm{mmol}$ ) and KOAc (142 mg, $1.50 \mathrm{mmol}$ ), flash evacuated and backfilled with nitrogen. $4 \mathrm{~mL}$ of dioxane was added and the resulting mixture stirred. The contents of the two reactions were mixed and bubbled with nitrogen to reduce oxygen. The resulting mixture was stirred at reflux $\left(80{ }^{\circ} \mathrm{C}\right)$ overnight. The crude product was purified by column chromatography with $20 \% \mathrm{MeOH}$ in DCM. Yield: $50 \%$. HRMS: calcd for $\mathrm{C}_{31} \mathrm{H}_{35} \mathrm{~N}_{2} \mathrm{O}_{6} \mathrm{~B}_{1}$ 542.258270, found 542.257887. ${ }^{1} \mathrm{H}$ NMR (400 MHz, MeOD) $\delta 7.83$ $(\mathrm{d}, J=7.6,2 \mathrm{H}), 7.71(\mathrm{~d}, J=7.3,2 \mathrm{H}), 7.58(\mathrm{~d}, J=7.6,1 \mathrm{H}), 7.44-7.33$ (ddd, $J=32.6,14.6,7.4,4 \mathrm{H}), 7.26(\mathrm{dd}, J=10.1,6.2,2 \mathrm{H}), 4.84(\mathrm{~m}$, $1 \mathrm{H}), 4.43(\mathrm{~d}, J=6.8,2 \mathrm{H}), 4.26(\mathrm{t}, J=6.8,1 \mathrm{H}), 4.18(\mathrm{~s}, 2 \mathrm{H}), 1.44(\mathrm{~d}$, $J=6.4,3 \mathrm{H}), 1.31(\mathrm{~s}, 12 \mathrm{H}) .{ }^{13} \mathrm{C} \mathrm{NMR}(100 \mathrm{MHz}, \mathrm{MeOD}) \delta 172.26$, $169.70,143.83,141.24,133.13,132.99,127.44,126.80,124.80$, 119.56, 69.05, 66.94, 42.84, 30.41, 29.49, 29.38, 29.08, 24.76.

Synthesis of ROS cleavable linker 1a (3-[Fmoc-Gly]amino-4(4,4,5,5-tetramethyl-1,3,2-dioxaborolan-2-yl)phenylethyl 2,5-dioxo1-pyrrolidinyl ester carbonic acid). To the stirred solution of 9 (200 mg, $0.37 \mathrm{mmol}$ ) in dry MeCN/DCM (7.5 mL), $N, N^{\prime}$-disuccinimidyl carbonate $(142.17 \mathrm{mg}, 0.56 \mathrm{mmol})$ was added at room temperature under a $\mathrm{N}_{2}$ atmosphere. To the cloudy suspension, triethylamine $(154 \mu \mathrm{L}, 1.11 \mathrm{mmol})$ was added, and after a couple of minutes the reaction mixture turned clear. The reaction was completed after $4 \mathrm{~h}$. The solvent was removed in vacuo. The residue was dissolved in $6 \mathrm{~mL} \mathrm{CH}_{2} \mathrm{Cl}_{2}$, and washed with $3 \times 3 \mathrm{~mL}$ saturated $\mathrm{NaHCO}_{3}$. The organic phase was washed with $4 \mathrm{~mL}$ brine and dried with anhydrous $\mathrm{MgSO}_{4}$, and the solvent was removed in vacuo. The crude product was purified by column chromatography eluting with $70 \%$ EtOAc in hexane. Yield: $30 \%$. HRMS: calcd for $\mathrm{C}_{36} \mathrm{H}_{39} \mathrm{~N}_{3} \mathrm{O}_{10} \mathrm{~B}_{1} 684.345070$, found 684.345500. ${ }^{1} \mathrm{H}$ NMR (400 MHz, MeOD) $\delta 7.96(\mathrm{~d}, J=1.5,1 \mathrm{H}), 7.82(\mathrm{~d}, J=7.4,2 \mathrm{H}), 7.71$ $(\mathrm{m}, 2 \mathrm{H}), 7.58(\mathrm{~d}, J=8.2,1 \mathrm{H}), 7.46-7.30(\mathrm{~m}, 4 \mathrm{H}), 7.16(\mathrm{~m}, 1 \mathrm{H}), 4.82$ $(\mathrm{m}, 1 \mathrm{H}), 4.46(\mathrm{~d}, J=6.7,2 \mathrm{H}), 4.27(\mathrm{t}, J=7.5,1 \mathrm{H}), 3.98(\mathrm{~s}, 2 \mathrm{H}), 1.44$ $(\mathrm{d}, J=6.6,3 \mathrm{H}), 1.30(\mathrm{~s}, 4 \mathrm{H}), 1.22(\mathrm{~s}, 12 \mathrm{H}) .{ }^{13} \mathrm{C}$ NMR $(126 \mathrm{MHz}$, MeOD) $\delta 169.94,168.86,157.82,147.18,143.89,141.20,140.32$, $128.90,128.39,127.40,126.78,124.85,121.07,119.53,118.70$, $117.15,80.29,69.31,66.80,43.94,28.98,23.65$.

Synthesis of ROS cleavable linker 1b (3-[Fmoc-Gly]amino-4(4,4,5,5-tetramethyl-1,3,2-dioxaborolan-2-yl)phenylethyl 4-nitrophenyl ester carbonic acid). Benzyl alcohol derivative 9 (0.4 g, $0.74 \mathrm{mmol}$ ) was dissolved in $7.4 \mathrm{~mL}$ of a dry mix of DCM/THF (1:1) under $\mathrm{N}_{2}$. Pyridine (anhydrous) (0.12 mL, $1.48 \mathrm{mmol}$ ) was added followed by 4-nitrophenyl chloroformate $(0.16 \mathrm{~g}, 0.81 \mathrm{mmol})$ and the reaction was allowed to stir at room temperature for $12 \mathrm{~h}$. The reaction was diluted with EtOAc and washed with $1 \mathrm{M} \mathrm{HCl}$ followed by saturated $\mathrm{NaHCO}_{3}$. The organic layer was dried over $\mathrm{MgSO}_{4}$, filtered and concentrated. Compound $\mathbf{1 b}$ was purified on a silica gel column eluting with 5\% EtOAc in hexane. Yield: $60 \%$. HRMS: calcd for $\mathrm{C}_{38} \mathrm{H}_{38} \mathrm{~N}_{3} \mathrm{O}_{10} \mathrm{~B}_{1} 707.264480$, found 707.264750. ${ }^{1} \mathrm{H}$ NMR (500 MHz, MeOD) $\delta 8.00(\mathrm{~s}, 1 \mathrm{H}), 7.80$ $(\mathrm{t}, J=8.3,3 \mathrm{H}), 7.70(\mathrm{~d}, J=7.3,3 \mathrm{H}), 7.59(\mathrm{~d}, J=8.3,1 \mathrm{H}), 7.44-7.27$ $(\mathrm{m}, 6 \mathrm{H}), 7.12(\mathrm{~d}, J=8.0,1 \mathrm{H}), 5.84(\mathrm{dd}, J=12.8,6.2,1 \mathrm{H}), 4.46(\mathrm{~d}$, $J=6.7,2 \mathrm{H}), 4.27(\mathrm{t}, J=6.6,1 \mathrm{H}), 3.99(\mathrm{~s}, 2 \mathrm{H}), 1.52(\mathrm{~d}, J=7.6,3 \mathrm{H})$, 1.27 (s, 12H). ${ }^{13} \mathrm{C}$ NMR (126 MHz, MeOD) $\delta$ 171.93, 169.25,
$143.82,142.43,141.24,135.36,132.39,127.43,126.80,124.80$, $119.58,83.26,74.45,71.76,66.90,46.98,35.00,34.52,28.98$, $28.45,26.44,26.34,25.86,25.84,23.96,23.94,23.65,21.06$.

\subsection{Synthesis of ROS-responsive delivery systems}

Synthesis of polymeric microspheres. $200 \mathrm{~nm}$ amino functionalised microspheres were synthesized following the methodology developed previously. ${ }^{37-39}$

Synthesis of probe 15. The dual-labelled $200 \mathrm{~nm}$ microspheres (15) and Cy5.5 labelled-microspheres (positive control) were prepared using an orthogonal Fmoc/Dde-based strategy following the solid phase protocol described in the ESI. $\dagger^{37-39}$ The colloidal stability of the microspheres was measured by Phase Analysis Light Scattering in the Zetasizer Nano ZS. It was observed that the values of zeta potential change significantly after each step.

Synthesis of ROS-responsive cell penetrating peptide mimetic (CPPM) probes 22 and 23. A highly-optimised microwave-based solid-phase strategy was used to synthesise the cell penetrating peptides. $^{24}$ An aminomethyl-PS (2\% DVB) resin functionalised with a Rink amide type linker was used for the synthesis of the peptides. An Fmoc-based reaction scheme was followed to obtain the desired probes following the methodology developed before $^{23}$ (see full details in the ESI $\dagger$ ).

\subsection{ROS-cleavable linker detection assay}

ROS cleavable linker $\mathbf{1 b}(1.4 \mathrm{mg})$ was dissolved in $2 \mathrm{~mL}$ of $2 \mathrm{M}$ hydrogen peroxide solution ( $1 \mathrm{mM}$ ), and was analysed by HPLC and LCMS to determine the cleavable products after $5 \mathrm{~min}$. ROS cleavable linker $\mathbf{1 b}$ was dissolved in $2 \mathrm{~mL}$ of water at $1 \mathrm{mM}$ as a control.

\subsection{Sensitivity test}

ROS-responsive cell penetrating peptide probes 22 and $23(20 \mu \mathrm{M})$ were incubated for 10 min with $\mathrm{H}_{2} \mathrm{O}_{2}(0-40 \mathrm{mM})$ in PBS $(1 \mathrm{~mL})$ and fluorescence emission at $\lambda_{\text {ex/em }} 485 / 528 \mathrm{~nm}$ for FAM/MR and 590/645 $\mathrm{nm}$ for Cy5.5/Cy7 was monitored $(n=3)$ in a BioTek microplate reader. Error is \pm standard deviation.

ROS-responsive microspheres probe 15 and Cy5.5 labelledmicrospheres (positive control) $\left(85 \mu \mathrm{g} \mathrm{mL}{ }^{-1}\right)$ were incubated with $\mathrm{H}_{2} \mathrm{O}_{2}(40 \mathrm{mM})$ in PBS $(1 \mathrm{~mL})$ and fluorescence emission at $\lambda_{\text {ex/em }} 590 / 645 \mathrm{~nm}$ for Cy5.5/Cy7 was monitored $(n=3)$ using a BioTek microplate reader. Also, the fluorescence was measured at $\lambda_{\text {ex/em }} 482 / 690 \mathrm{~nm}$, using a BD FACSAria flow cytometer. Fluorescence was evaluated as the mean fluorescence intensity (MFI) with 1000 events per sample plotted in two-dimensional dot plots based on forward and side scattering (SSC-H vs. FSC-H) to gate microsphere populations. The data were analysed using the software Flowjo ${ }^{\circledR}$ 7.5. Error is \pm standard deviation.

\subsection{Cellular assays}

Cell experiments were performed in a Heracell 150 incubator and carried out in a Herasafe KS 18 class II negative-flow cabinet from Heraeus. RAW 264.7 (mouse leukaemic monocyte macrophage cell line) was from The European Collection of Animal Cell Cultures (ECACC). Cells were cultured in DMEM containing high glucose $\left(4.5 \mathrm{mg} \mathrm{mL}^{-1}\right)$ supplemented with 

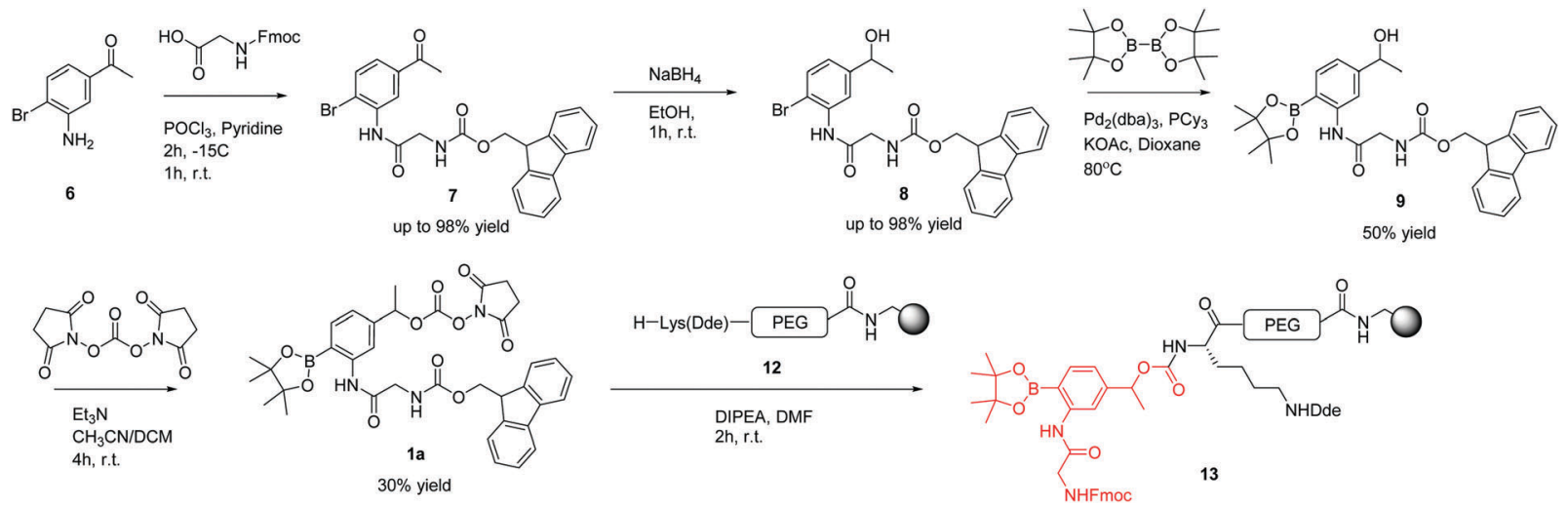

Scheme 1 Successful synthetic route towards the ROS-cleavable linker.

$4 \mathrm{mM}$ glutamine, 100 units per $\mathrm{mL}$ penicillin, $50 \mathrm{mg} \mathrm{mL}^{-1}$ streptomycin, and $10 \%$ FBS. The cells were maintained in a humid chamber at $37^{\circ} \mathrm{C}$ in an atmosphere of $5 \% \mathrm{CO}_{2}$ in $\mathrm{T} 75$ cell culture flasks until $70 \%$ confluency. RAW 264.7 macrophage cells in their complete growth medium were transferred $(100000$ cells per well) to 24-well plates. To activate $\mathrm{H}_{2} \mathrm{O}_{2}$ production, $\mathrm{PbCrO}_{4}$ was added $(150 \mu \mathrm{M})$ and incubated for $20 \mathrm{~min}$. After the removal of media, ROS-responsive cell penetrating peptide probes 22-23 and CPPM positive control $(5 \mu \mathrm{M})$ or ROS-responsive microspheres probe 15 and Cy5.5 labelled-microspheres positive control $\left(85 \mu \mathrm{g} \mathrm{mL}{ }^{-1}\right)$ were incubated overnight. Then, cells were washed twice with PBS and detached with trypsin/EDTA, harvested with $2 \%$ fetal bovine serum (FBS) in PBS (supplemented with Trypan Blue (0.04\%) for FITC), analysing using a BD FACSAria

Table 1 Reagents and reaction conditions used for optimisation of the synthesis of compound 9

\begin{tabular}{|c|c|c|c|c|}
\hline Reagents & $\begin{array}{l}\text { Ratios } \\
(\mathbf{8})^{a}\end{array}$ & $\begin{array}{l}\text { Solvent/Conc. } \\
\text { of substrate (8) }\end{array}$ & Conditions & $\begin{array}{l}\text { Yield } \\
(\%)\end{array}$ \\
\hline $\begin{array}{l}\mathrm{PdCl}_{2}(\mathrm{dppf}) \\
\mathrm{KOAc}\end{array}$ & $\begin{array}{l}0.03 \\
1.5\end{array}$ & Dioxane/0.1 M & $24 \mathrm{~h} 80^{\circ} \mathrm{C}$ & 14 \\
\hline $\begin{array}{l}\mathrm{PdCl}_{2}(\mathrm{dppf}) \\
\mathrm{KOAc}\end{array}$ & $\begin{array}{l}0.03 \\
1.5\end{array}$ & Dioxane/0.1 M & $48 \mathrm{~h} 80{ }^{\circ} \mathrm{C}$ & 19 \\
\hline $\begin{array}{l}\mathrm{PdCl}_{2}(\mathrm{dppf}) \\
\mathrm{Et}_{3} \mathrm{~N}\end{array}$ & $\begin{array}{l}0.03 \\
1.5\end{array}$ & Dioxane/0.1 M & $3 \mathrm{~h} 100{ }^{\circ} \mathrm{C}$ & 14 \\
\hline $\begin{array}{l}\mathrm{Pd}_{2}(\mathrm{dba})_{3} \\
\mathrm{PCy}_{3} \\
\text { KOAc }\end{array}$ & $\begin{array}{l}0.03 \\
0.07 \\
1.5\end{array}$ & $\begin{array}{l}\text { Dioxane } / \mathrm{H}_{2} \mathrm{O} \\
(1: 3) / 0.2 \mathrm{M}\end{array}$ & $\begin{array}{l}3 \mathrm{~h} 80{ }^{\circ} \mathrm{C} \text { microwave } \\
\text { heating }\end{array}$ & - \\
\hline $\begin{array}{l}\mathrm{Pd}_{2}(\mathrm{dba})_{3} \\
\mathrm{PCy}_{3} \\
\mathrm{KOAc}\end{array}$ & $\begin{array}{l}0.03 \\
0.07 \\
1.5\end{array}$ & $\begin{array}{l}\mathrm{DMF} / \mathrm{H}_{2} \mathrm{O} \\
(1: 3) / 0.2 \mathrm{M}\end{array}$ & $\begin{array}{l}3 \mathrm{~h} 80{ }^{\circ} \mathrm{C} \text { microwave } \\
\text { heating }\end{array}$ & - \\
\hline $\begin{array}{l}\mathrm{Pd}_{2}(\mathrm{dba})_{3} \\
\mathrm{PCy}_{3} \\
\mathrm{KOAc}\end{array}$ & $\begin{array}{l}0.03 \\
0.07 \\
1.5\end{array}$ & Dioxane/0.2 M & $6 \mathrm{~h} 80{ }^{\circ} \mathrm{C}$ & 31 \\
\hline $\begin{array}{l}\mathrm{Pd}_{2}(\mathrm{dba})_{3} \\
\mathrm{PCy}_{3} \\
\mathrm{KOAc}\end{array}$ & $\begin{array}{l}0.03 \\
0.07 \\
1.5\end{array}$ & $\begin{array}{l}\text { Dioxane } \\
\text { bubbled/0.2 M }\end{array}$ & $6 \mathrm{~h} 80^{\circ} \mathrm{C}$ & 50 \\
\hline
\end{tabular}

flow cytometer. Cellular fluorescence of cells was analysed in a Zeiss Axiovert 200M pseudo confocal microscope with a $100 \mathrm{~W} \mathrm{Hg}$ lamp or in a Leica SP5 Confocal (GFP and RFP channel).

\section{Results and discussion}

The ROS-cleavable linker was synthesised in 4 steps following the approach shown in Scheme 1.

Compound 7 was synthesised from 3-amino-4-bromoacetophenone 6 by the amide coupling of Fmoc-Gly-OH. Presumably due to the poor nucleophilic behaviour and steric bulk of the bromoaniline, compound 7 was only obtained using the acid chloride of Fmoc-Gly-OH, generated using phosphoryl chloride $(5.8 \% \mathrm{w} / \mathrm{v})$ in pyridine for $2 \mathrm{~h}$ at $-15{ }^{\circ} \mathrm{C}$.

Following successful amide bond formation, the ketone was simply reduced by $\mathrm{NaBH}_{4}$ to give alcohol 8 . Palladium mediated conversion of the bromide to the boronic ester was problematic and took extensive optimisation (Table 1). The use of the ligand

Table 2 Reagents and reaction conditions used in the optimisation of the synthesis of the ROS-cleavable linkers $1 \mathbf{a} / \mathbf{1} \mathbf{b}$

\begin{tabular}{|c|c|c|c|c|}
\hline Reagents & $\begin{array}{l}\text { Ratios } \\
\text { (9) }\end{array}$ & $\begin{array}{l}\text { Solvent/Conc. } \\
\text { of substrate (9) }\end{array}$ & Conditions & $\begin{array}{l}\text { Yield } \\
(\%)\end{array}$ \\
\hline BTC & 2 & DCM/0.1 M & $1 \mathrm{~h} 0{ }^{\circ} \mathrm{C}$ & - \\
\hline TEA & 1 & & 6 h r.t. & \\
\hline BTC & 2.3 & $\mathrm{DCM} / 0.1 \mathrm{M}$ & $2 \mathrm{~h}$ & - \\
\hline Pyridine & 13.5 & & & \\
\hline BTC & 0.1 & $\mathrm{DMF} / \mathrm{CH}_{3} \mathrm{CN}(1: 1) / 0.1 \mathrm{M}$ & $24 \mathrm{~h}$ & - \\
\hline CDI & 4 & $\mathrm{DMF} / 0.2 \mathrm{M}$ & $24 \mathrm{~h}$ & - \\
\hline DMAP & 0.5 & & & \\
\hline $4 \mathrm{NO}_{2} \mathrm{PhCOCl}$ & 1.1 & $\mathrm{THF} / 0.1 \mathrm{M}$ & $2 \mathrm{~h}$ & - \\
\hline TEA & 2 & & & \\
\hline $4 \mathrm{NO}_{2} \mathrm{PhCOCl}$ & 2 & $\mathrm{DCM} / 0.8 \mathrm{M}$ & $3 \mathrm{~h}$ & 10 \\
\hline Pyridine & 3 & & & \\
\hline DSC & 1 & $\mathrm{CH}_{3} \mathrm{CN} / \mathrm{DCM}(1: 1) / 0.4 \mathrm{M}$ & $4 \mathrm{~h}$ & $30(\mathbf{1 a})$ \\
\hline $\mathrm{Et}_{3} \mathrm{~N}$ & 2 & & & \\
\hline $4 \mathrm{NO}_{2} \mathrm{PhCOCl}$ & 2 & DCM/THF $(7: 3) / 0.4 \mathrm{M}$ & $\mathrm{o} / \mathrm{n}$ & $60(\mathbf{1 b})$ \\
\hline Pyridine & 3 & & & \\
\hline
\end{tabular}


tricyclohexylphosphine and the palladium catalyst $\mathrm{Pd}_{2}(\mathrm{dba})_{3}$ gave the desired product in $50 \%$ yield.

The next step was the activation of the secondary alcohol group. Several strategies were tried, including triphosgene bis(trichloromethyl) carbonate (BTC), 4-nitrophenyl chloroformate, 1,1'-carbonyldiimidazole (CDI), and $N, N^{\prime}$-disuccinimidyl carbonate (DSC) (Table 2).

To test whether the linker was cleaved by $\mathrm{H}_{2} \mathrm{O}_{2}$, linker $\mathbf{1 b}$ (3-[Fmoc-Gly]amino-4-(4,4,5,5-tetramethyl-1,3,2-dioxaborolan-2yl)phenylethyl 4-nitrophenyl ester carbonic acid) was treated with hydrogen peroxide and analysed by HPLC/LCMS. This clearly

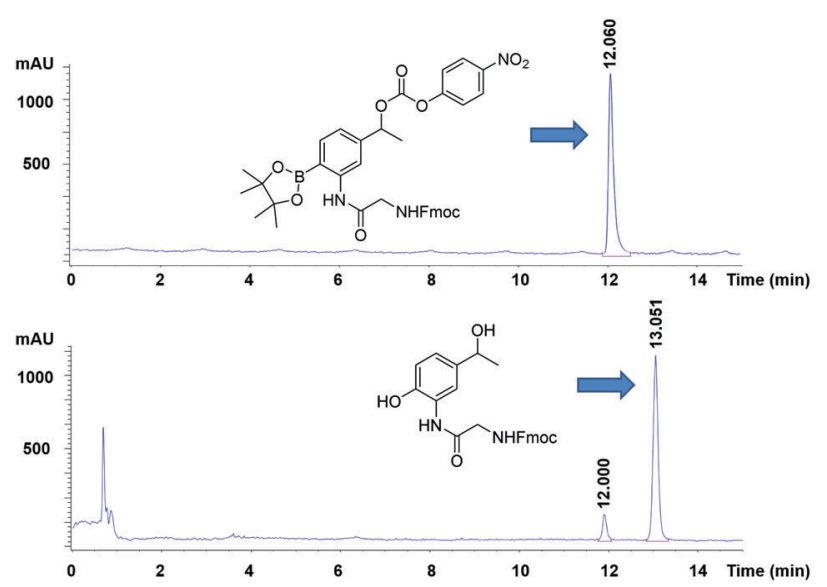

Fig. 2 HPLC chromatograms (detection at $254 \mathrm{~nm}$ ) of (upper) the linker (1) (lower) its cleavage products following treatment with peroxide.
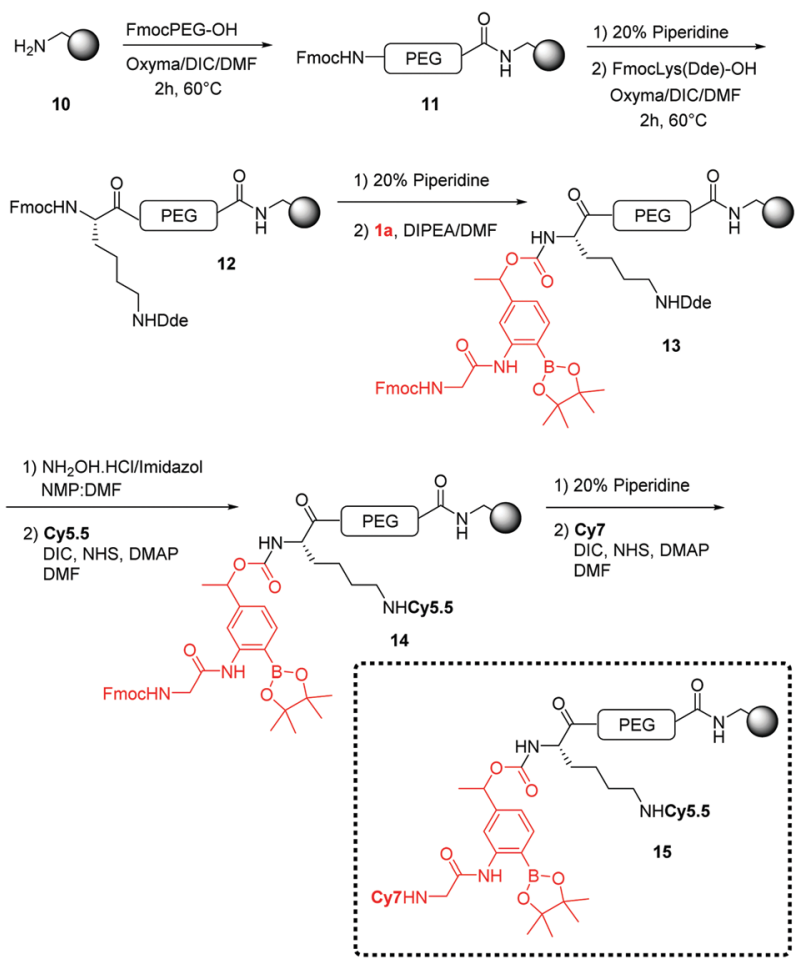

Scheme 2 General synthesis for the generation of ROS-responsive microspheres (15). showed (Fig. 2) the generation of the phenol derivative (2-[FmocGly]amino-4-hydroxyethylphenol), a product of the 1,6-elimination reaction generated by the oxidation of the boronic acid in the classical boronic acid to phenol rearrangement.

Using 4-nitrophenyl chloroformate or $N, N^{\prime}$-disuccinimidyl carbonate, the linker was successfully activated to give the 4-nitrophenyl and succinimidyl carbonates respectively. However, 4-nitrophenol was not a good enough leaving group to enable coupling to the amino derivatised microspheres, whereas the $\mathrm{N}$-hydroxysuccinimide was. This then allowed solid-phase orthogonal chemistry (based on Dde and Fmoc protecting group chemistry ${ }^{36}$ to allow coupling of peptide cargos/dyes to the microspheres (Scheme 2).

The polymeric microspheres were synthesized by an emulsifierfree emulsion polymerisation ${ }^{16}$ where vinylbenzylamine hydrochloride salt (VBAH) acts as the emulsifier and is copolymerized with styrene along with $p$-divinylbenzene (DVB) as a cross-linking

a)

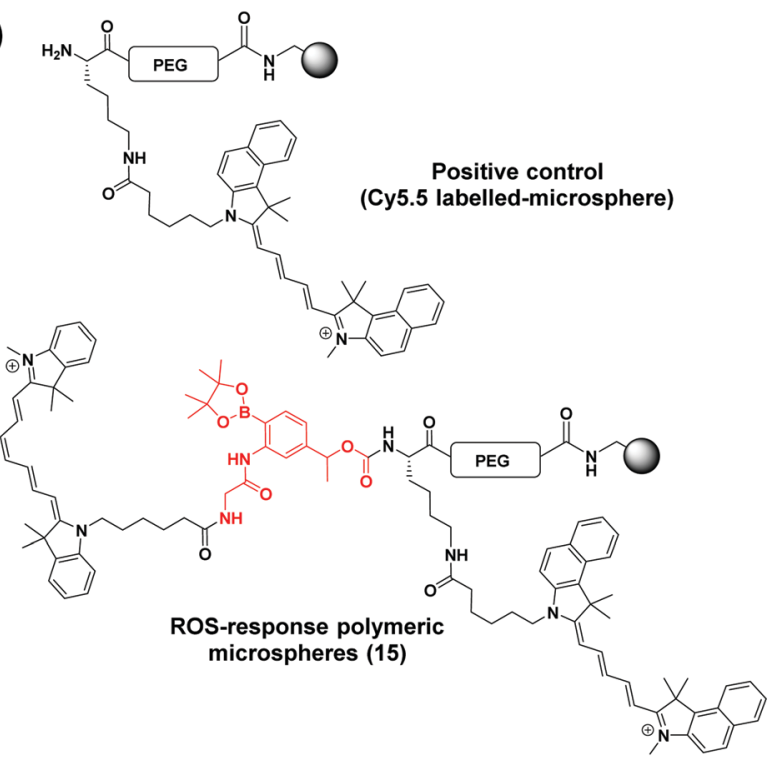

b)

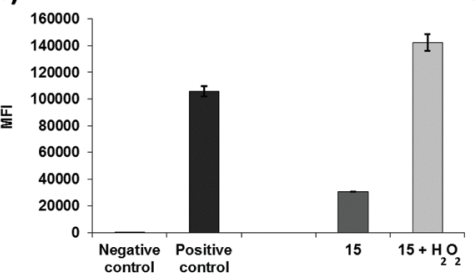

c)

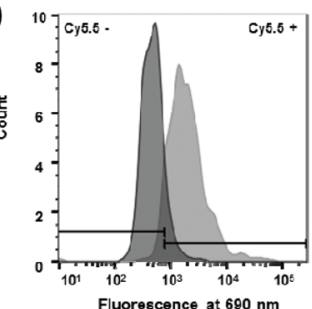

Fig. 3 (a) Design of ROS-responsive polymeric microspheres (15) as a FRETbased probe attached to the ROS-cleavable linker (1a), which is cleaved by oxidative conditions perturbing the FRET system (consisting of NIR cyanine dyes Cy5.5 $\left(\lambda_{\text {ex }} / \lambda_{\text {em }} 675 / 694 \mathrm{~nm}\right) /$ Cy7 $\left.\left(\lambda_{\text {ex }} / \lambda_{\text {em }} 743 / 767 \mathrm{~nm}\right)\right)$. (b) Flow cytometry analysis of the fluorescence intensity. The ROS-responsive polymeric microspheres (15) showed a > than 3-fold fluorescence increase after $10 \mathrm{~min}$ incubation with $\mathrm{H}_{2} \mathrm{O}_{2}(40 \mathrm{mM})$. (c) Histograms of microspheres probe 15 before (dark grey) and after (light grey) the addition of $\mathrm{H}_{2} \mathrm{O}_{2}\left(\lambda_{\mathrm{ex}} / \lambda_{\mathrm{em}} 482 / 690 \mathrm{~nm}\right)$, using a BD FACSAria flow cytometer. Fluorescence was evaluated as the mean fluorescence intensity (MFI) with 1000 events per sample plotted in two-dimensional dot plots based on forward and side scattering (SSC-H vs. FSC-H) to gate microsphere populations. The data were analysed using the software Flowjo ${ }^{\mathbb{R}} 7.5$. 
agent (see ESI $\dagger$ ). A Cy5.5/Cy7 FRET pair was used to allow evaluation of cellular-uptake efficiency and monitoring of ROSproduction. The dual-labelled $200 \mathrm{~nm}$ microspheres (loading $0.2 \mathrm{mmol} \mathrm{g}^{-1}$ ) were prepared using an orthogonal Fmoc/Dde-based strategy. Fmoc-PEG-OH was coupled onto the microspheres followed by coupling of Fmoc-Lys(Dde)-OH and attachment of the linker 1 1a. $^{18}$ The Dde protecting group was selectively removed ${ }^{36}$ followed by the addition of Cy5.5. The dye Cy7 was coupled following Fmoc cleavage (see Scheme 2).

To test the efficiency of ROS-responsive microspheres (15) for the monitoring of oxidative species in solution, a flow cytometry assay was performed on the beads with probe $\mathbf{1 5}$ incubated with $\mathrm{H}_{2} \mathrm{O}_{2}$ (see Fig. 3). This showed a > 3-fold Cy5.5fluorescence increase and confirms Cy5.5 fluorescence quenching (Cy5.5/Cy7 FRET) with disruption of this FRET pair through cleavage of the ROS-linker.

Another approach to confirm the efficiency of the ROS-sensitive linker was designed using a cell penetrating peptide as a carrier system. This consisted of the polycationic $N$-alkylglycine peptide $^{24-34}$ connected to the ROS-cleavable linker $\mathbf{1 b}$ (which showed high coupling efficiency to the Rink amide resin than 1a), but with cellular uptake blocked due to the interaction with a polyanionic chain $\left(\mathrm{L}-\mathrm{Glu}_{9}\right)$ analogous to the system of Tsein (for synthesis details, see the ESI $\dagger$ ). The ROS-responsive cell penetrating peptides 22-23 were synthesized on a Rink amide-functionalised aminomethyl polystyrene resin using an Fmoc/tBu-based strategy and labeled with the fluorophores 5(6)-carboxyfluorescein or Cy5.5 and the corresponding quenchers methyl red and Cy7 (see Scheme 3). ${ }^{23,24}$ After deprotection and cleavage from the resin with TFA/TIS, the ROS-responsive Activatable Cell Penetrating Peptides were purified by preparative HPLC and analysed with structures confirmed by MALDI-TOF MS.

The efficiency of the release of the cargos was evaluated in solution assays with monitoring of the fluorescence increase when probes 22 and $\mathbf{2 3}$ were incubated with increasing concentrations

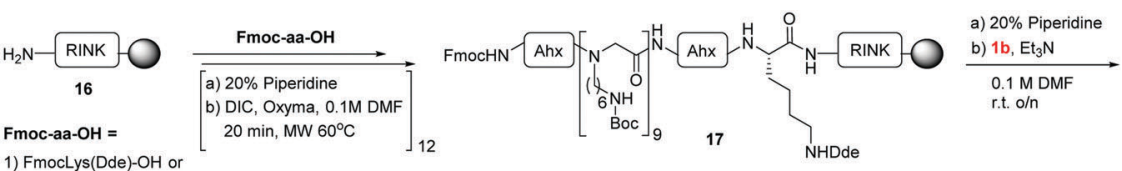

1) FmocLys(Dde)-OH

2) FmocAhx-OH or

3) $\mathrm{FmOCN} \Upsilon \mathrm{OH}$

GNHBoc

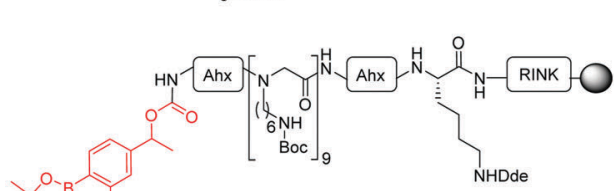

Fmoc-aa-OH = 1) FmocAhx-OH or 2) $\mathrm{FmocGlu}(\mathrm{OtBu})-\mathrm{OH}$
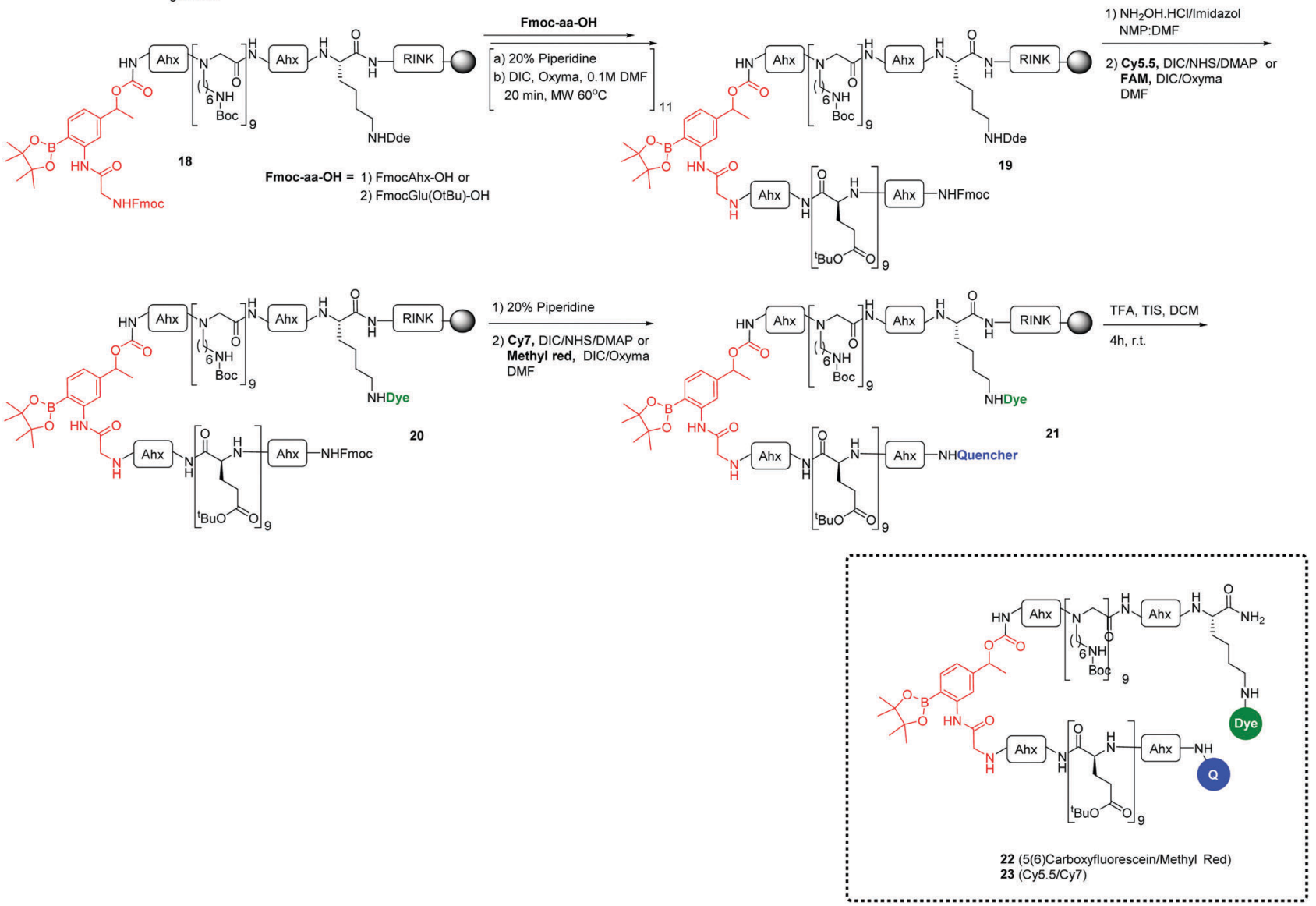

Scheme 3 General synthesis of ROS-responsive cell penetrating peptides (22 and 23). 
of $\mathrm{H}_{2} \mathrm{O}_{2}$ (Fig. 4b) and showed a 6-fold fluorescence increase for the peptide 22 carrying the FAM/MR pair and a 15 -fold fluorescence increment for the peptide 23 which contained the Cy5.5/Cy7 couple.

RAW 264.7 macrophage cells (mouse leukemic macrophage) are a cell line established from a tumor induced by Abelson murine leukemia virus. They are capable of producing $\mathrm{H}_{2} \mathrm{O}_{2}$ upon stimulation with various inorganic/organic molecules. ${ }^{40,41}$

Probes 15 and 23 were incubated in either oxidative or nonoxidative environments, with RAW macrophage cells and cell fluorescence analysed by flow cytometry and fluorescence microscopy. It has been shown that $\mathrm{PbCrO}_{4}$ can be phagocytized by cells and can accumulate within vacuoles in the cytoplasm. $\mathrm{Cr}(\mathrm{vI})$ compounds undergo a complex metabolic reducing pathway, which generates a variety of reactive forms of chromium and ROS, and generate hydroxyl radicals $\left({ }^{\bullet} \mathrm{OH}\right)$ from $\mathrm{H}_{2} \mathrm{O}_{2}$ via a Fenton-like reaction. Also, during the cellular $\mathrm{Cr}(\mathrm{vI})$ reduction process, molecular oxygen is consumed to generate superoxide anion radicals $\left(\mathrm{O}_{2}{ }^{-}\right)$and $\mathrm{H}_{2} \mathrm{O}_{2}{ }^{42}$

When RAW cells were treated with the ROS-responsive microspheres (probe 15) $\left(85 \mu \mathrm{g} \mathrm{mL}{ }^{-1}\right.$ ) and were stimulated with $\mathrm{PbCrO}_{4}$ $(150 \mu \mathrm{M})$ the flow cytometric histograms showed $>20$-fold more fluorescence for ROS-production stimulated cells (Fig. 5a). Semiconfocal microscopy confirmed that the fluorescence signal was far greater after linker cleavage (Fig. 5c and d), confirming the results obtained by flow cytometry.

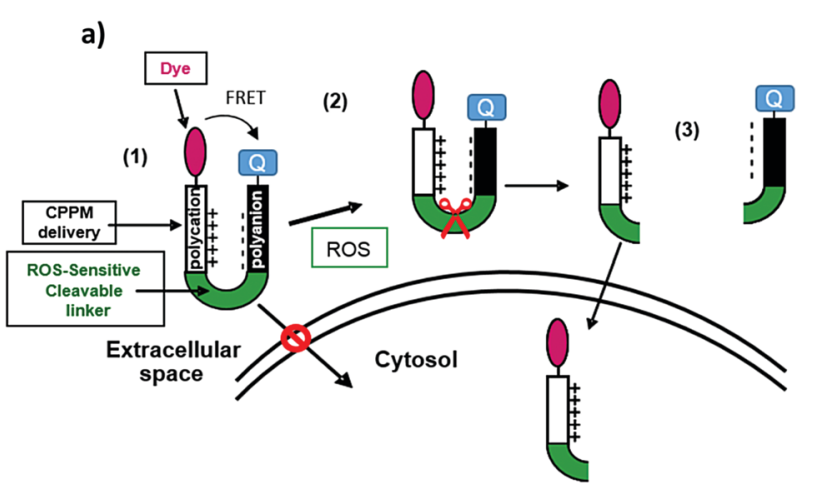

b)

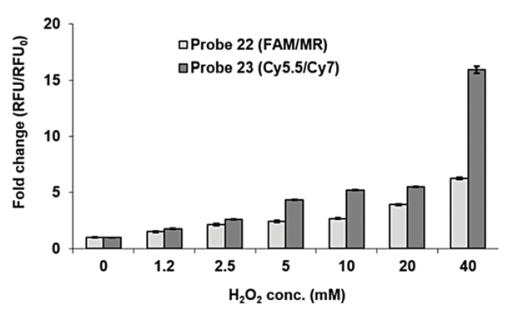

Fig. 4 (a) ROS-responsive cell penetrating probes (22 and 23 ) - the reactive oxygen species - the activatable cell penetrating strategy. (a) (1) Blocked cellular uptake of the delivery system due to neutralisation/interaction with the polyanionic chain; (2) selective extracellular cleavage of the linker by the reactive oxygen species and (3) the liberated polycationic peptide linked to the dye can enter the cell. (b) Analysis of the cell penetrating peptides $\mathbf{2 2}$ and 23 (at $20 \mu \mathrm{M}$ ) with differing concentrations of hydrogen peroxide (measured 10 min after addition of $\mathrm{H}_{2} \mathrm{O}_{2}$ ): peptide $22, \lambda_{\text {ex/em }} 485 / 528 \mathrm{~nm}$ or 23 , $\lambda_{\text {ex/em }} 590 / 645 \mathrm{~nm}$ (Cy5.5 $\lambda_{\text {ex/em }} 675 / 694 \mathrm{~nm}$ and Cy7 $\lambda_{\text {ex/em }} 743 / 767 \mathrm{~nm}$ ). a)
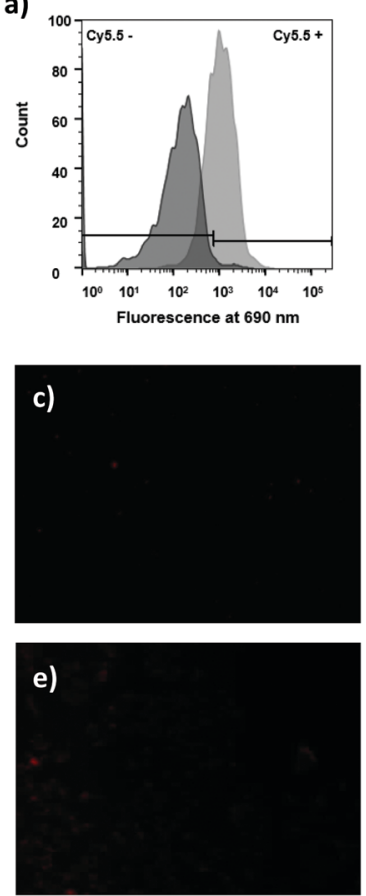

b)
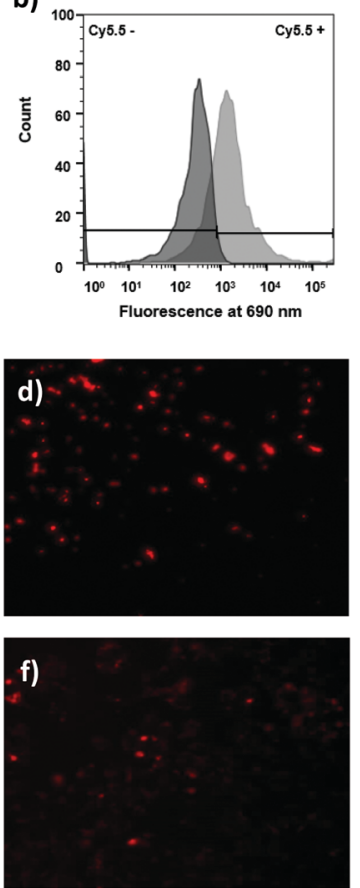

Fig. 5 Assessment of the ROS-sensitive linker in probes $\mathbf{1 5}$ and $\mathbf{2 3}$ in live RAW cells showing cleavage by $\mathrm{H}_{2} \mathrm{O}_{2}$, as demonstrated by FACS analysis and microscopy. Histograms of RAW cells incubated with (a) ROS-sensitive microspheres probe $15\left(85 \mu \mathrm{g} \mathrm{mL}^{-1}\right.$ ) (dark grey) and probe $15\left(85 \mu \mathrm{g} \mathrm{mL}^{-1}\right)+$ $\mathrm{PbCrO}_{4}$ (150 $\mu \mathrm{M}$ for 20 min) (light grey) or incubated with (b) ROS-sensitive cell penetrating peptide probe $23(5 \mu \mathrm{M})$ (dark grey) and probe $23(5 \mu \mathrm{M})+$ $\mathrm{PbCrO}_{4}(150 \mu \mathrm{M}$ for 20 min) (light grey). (c-f) Zeiss Axiovert 200M pseudo confocal microscope images of RAW cells analysed under a Cy5 filter $\left(\lambda_{\text {ex }} / \lambda_{\text {em }} 640 / 690 \mathrm{~nm}\right)$, with a $\times 20$ objective (c) after incubation with 15 (85 $\mu \mathrm{g} \mathrm{mL}^{-1}$ ) and (d) after incubation with $15\left(85 \mu \mathrm{g} \mathrm{mL}^{-1}\right)+\mathrm{PbCrO}_{4}$ (150 $\mu \mathrm{M}$ for $20 \mathrm{~min})$; (e) after incubation with $23(5 \mu \mathrm{M})$ and (f) after incubation with $23(5 \mu \mathrm{M})+\mathrm{PbCrO}_{4}(150 \mu \mathrm{M}$ for 20 min). Red fluorescence dots are from Cy5.5 "turned on" by hydrogen peroxide cleavage of the ROSsensitive linker in the ROS-sensitive microspheres probe $\mathbf{1 5}$ (upper) and the ROS-sensitive cell penetrating peptide probe $\mathbf{2 3}$ (lower) inside the cytoplasm of RAW macrophage cells.

It was explored whether the ROS-responsive cell penetrating peptide (probe 23) ( $5 \mu \mathrm{M}$ ) could be used to detect $\mathrm{H}_{2} \mathrm{O}_{2}$ in the cellular environment as observed previously using the ROSresponsive microspheres. Probe 23 was incubated with RAW cells with/without $\mathrm{PbCrO}_{4}$ and analysed by flow cytometry and fluorescence microscopy. In this case, the flow cytometric histograms showed a 6-fold fluorescence increment for cells treated with $\mathrm{PbCrO}_{4}$ (Fig. 5b), corroborating the successful cleavage of the ROS-sensitive linker when the $\mathrm{H}_{2} \mathrm{O}_{2}$ level increased.

\section{Conclusions}

In conclusion an efficient route towards synthesizing a ROScleavable linker that is sensitive to $\mathrm{H}_{2} \mathrm{O}_{2}$ has been developed. This linker allowed the design of ROS-responsive delivery systems able to liberate cargos selectively into the cellular cytoplasm in an oxidative environment. 
The synthesis of a ROS-responsive polymer delivery system that detects ROS inside cells allowed the release of the cargos in the cellular cytoplasm. Cell penetrating peptide mimetics were designed with penetrating properties disrupted through a hairpin structure with a FRET pair, and the cleavage of the linker permits the internalization of labelled-peptides. In live cells, fluorescence increases were detected by flow cytometry, confirming the potential of these ROS-responsive delivery systems for imaging of the oxidative environment. Based on these studies, phagocytic cells (macrophages) which generate high levels of $\mathrm{H}_{2} \mathrm{O}_{2}$ could be monitored thanks to the efficient cleavage of this ROS-sensitive linker. Importantly, a similar targeting mechanism could be further used for directed delivery of therapeutic cargos.

\section{Acknowledgements}

The authors would like to thank the Caja Madrid and Ramon Areces Foundations for funding AMPL. EV acknowledges European Union Seventh Framework Programme FP7 2012 for financial support. The research leading to these results has received funding from the European Union Seventh Framework Programme FP7 2012 under grant agreement no. 327903 (E. V.).

\section{Notes and references}

1 G. S. Devi, M. H. Prasad, D. Raghu, D. N. Rao and P. P. Reddy, Clin. Chim. Acta, 2000, 293, 53-62.

2 G. Poli, F. Biasi and E. Chiarpotto, Curr. Med. Chem., 2004, 11, 1163-1182.

3 T. Finkel, J. Cell Biol., 2011, 194, 7-15.

4 J. Chandra, A. Samali and S. Orrenius, Free Radical Biol. Med., 2000, 29, 323-333.

5 W. Droge, Physiol. Rev., 2002, 82, 47-95.

6 L. Pecorino, Molecular Biology of Cancer: Mechanisms, Targets, and Therapeutics, 3rd edn, Oxford, 2012.

7 C. de Gracia Lux, S. Joshi-Barr, T. Nguyen, E. Mahmoud, E. Schopf, N. Fomina and A. Almutairi, J. Am. Chem. Soc., 2012, 134, 15758-15764.

8 J. Liu, Y. Pang, Z. Zhu, D. Wang, C. Li, W. Huang, X. Zhu and D. Yan, Biomacromolecules, 2013, 14, 1627-1636.

9 Y. Kuang, K. Balakrishnan, V. Gandhi and X. Peng, J. Am. Chem. Soc., 2011, 133, 19278-19281.

10 E. J. Kim, S. Bhuniya, H. Lee, H. Min Kim, C. Cheong, S. Maiti, K. S. Hong and J. S. Kim, J. Am. Chem. Soc., 2014, 136, 13888-13894.

11 G. C. Van de Bittner, E. A. Dubikovskaya, C. R. Bertozzi and C. J. Chang, Proc. Natl. Acad. Sci. U. S. A., 2010, 107, 21316-21321.

12 G. C. Van de Bittner, C. R. Bertozzi and C. J. Chang, J. Am. Chem. Soc., 2013, 135, 1783-1795.

13 D. Lee, S. Khaja, J. C. Velasquez-Castano, M. Dasari, C. Sun, J. Petros, W. R. Taylor and N. Murthy, Nat. Mater., 2007, 6, 765-769.
14 N. Karton-Lifshin, E. Segal, L. Omer, M. Portnoy, R. Satchi-Fainaro and D. Shabat, J. Am. Chem. Soc., 2011, 133, 10960-10965.

15 R. Weinstain, E. N. Savariar, C. N. Felsen and R. Y. Tsien, J. Am. Chem. Soc., 2014, 136, 874-877.

16 R. Sanchez-Martin, M. Muzerelle, N. Chitkul, S. E. How, S. Mittoo and M. Bradley, ChemBioChem, 2005, 6, 1341-1345.

17 R. M. Sanchez-Martin, M. Cuttle, S. Mittoo and M. Bradley, Angew. Chem., Int. Ed., 2006, 45, 5472-5474.

18 J. M. Cardenas-Maestre, A. M. Perez-Lopez, M. Bradley and R. M. Sanchez-Martin, Macromol. Biosci., 2014, 14, 923-928.

19 C. Chung, D. Srikun, C. S. Lim, C. J. Chang and B. R. Cho, Chem. Commun., 2011, 47, 9618-9620.

20 V. V. Didenko, Biotechniques, 2011, 31, 1106-1121.

21 A. Solinas, L. J. Brown, C. McKenn, J. M. Mellor, J. T. G. Nicol, N. Thelwell and T. Brown, Nucleic Acids Res., 2011, 29, e96.

22 S. Zhang, V. Metelev, D. Tabatadze, P. C. Zamecnik and A. Bogdanov, Proc. Natl. Acad. Sci. U. S. A., 2008, 105, 4156-4161.

23 T. Jong, A. M. Pérez-López, E. M. V. Johansson, A. Lilienkampf and M. Bradley, Bioconjugate Chem., 2015, 26, 1759-1765.

24 M. A. Fara, J. J. Diaz-Mochon and M. Bradley, Tetrahedron Lett., 2006, 47, 1011-1014.

25 A. M. Pérez-López, M. L. Soria-Gila, E. R. Marsden, A. Lilienkampf and M. Bradley, PLoS One, 2016, 11, e0153209.

26 I. Peretto, R. Sanchez-Martin, X. Wang, J. Ellard, S. Mittoo and M. Bradley, Chem. Commun., 2003, 2312-2313.

27 P. A. Wender, D. J. Mitchell, K. Pattabiraman, E. T. Pelkey, L. Steinman and J. B. Rothbard, Proc. Natl. Acad. Sci. U. S. A., 2000, 97, 13003-13008.

28 A. Unciti-Broceta, F. Diezmann, C. Y. Ou-Yang, M. A. Fara and M. Bradley, Bioorg. Med. Chem., 2009, 3, 959-966.

29 K. Dhaliwal, L. Alexander, G. Escher, A. Unciti-Broceta, M. Jansen, N. Mcdonald, J. M. Cardenas-Maestre, R. SanchezMartin, J. Simpson, C. Haslett and M. Bradley, Faraday Discuss., 2011, 149, 107-114.

30 R. J. Simon, R. S. Kania, R. N. Zuckermann, V. D. Huebner, D. A. Jewell, S. Banville, S. Ng, L. Wang, S. Rosenberg, C. K. Marlowe, D. C. Spellmeyer, R. Tan, A. D. Frankel, D. V. Santi, F. D. Cohen and P. A. Bartlett, Proc. Natl. Acad. Sci. U. S. A., 1992, 89, 9367-9371.

31 R. N. Zuckermann, J. M. Kerr, S. B. H. Kent and W. H. Moos, J. Am. Chem. Soc., 1992, 114, 10646-10647.

32 K. Kirshenbaum, A. E. Barron, R. A. Goldsmith, P. Armand, E. K. Bradley, K. T. V. Truong, K. A. Dill, F. E. Cohen and R. N. Zuckermann, Proc. Natl. Acad. Sci. U. S. A., 1998, 95, 4303-4308.

33 R. N. Zuckermann and T. Kodadek, Curr. Opin. Mol. Ther., 2009, 11, 299-307.

34 J. T. Nguyen, C. W. Turck, F. E. Cohen, R. N. Zuckermann and W. A. Lim, Science, 1998, 282, 2088-2092. 
35 B. Chitkula, B. Atrasha and M. Bradley, Tetrahedron Lett., 2001, 42, 6211-6214.

36 J. J. Díaz-Mochón, L. Bialy and M. Bradley, Org. Lett., 2004, 6, 1127-1129.

37 R. M. Sanchez-Martin, L. Alexander, M. Muzerelle, J. M. Cardenas-Maestre, A. Tsakiridis, J. M. Brickman and M. Bradley, ChemBioChem, 2009, 10, 1453-1456.

38 F. Thielbeer, S. V. Chankeshwara and M. Bradley, Biomacromolecules, 2011, 12, 4386-4391.
39 A. Unciti-Broceta, E. M. V. Johansson, R. M. Yusop, R. M. Sánchez-Martín and M. Bradley, Nat. Protoc., 2012, 7, 1207-1218.

40 S. Y. Park, G. E. Ji, Y. T. Ko, H. K. Jung, Z. Ustunol and J. J. Pestka, Int. J. Food Microbiol., 1999, 46, 231-241.

41 P. Ping Wu, Z. Cai, J. Chen, H. Zhang and C. Cai, Biosens. Bioelectron., 2011, 26, 4012-4017.

42 S. S. Leonard, J. R. Roberts, J. M. Antonini, V. Castranova and X. Shi, Mol. Cell. Biochem., 2004, 255, 171-179. 